\title{
Imperative of A Statutory Framework For The Protection of Whistleblowers In Nigeria.
}

\author{
Professor E. Smaranda Olarinde \\ Provost College of Law, \\ Afe Babalola University, Ado-Ekiti. \\ Dr. Ebenezer T. Yebisi \\ College of Law, \\ Afe Babalola University, Ado-Ekiti.
}

\begin{abstract}
As secrecy is often a factor which permits many acts of corruption to go undetected or unreported, any programme which will encourage persons in the know of such acts to come forward and reveal them is welcome. However, as commendable as this current programme is, it still raises certain issues, the most prominent of which is the absence of a legal framework to guide the entire process and also the absence of any measure of protection to whistleblowers.
\end{abstract}

Afe Babalola, Nigerian Tribune, January 12, 2017.

\section{INTRODUCTION}

The latest approach to the unebbing problem of corruption and attendant looting of the official till, led to the introduction in Nigeria of a policy which allows citizens, who report corruption related offenses earn financial rewards, from loots recovered through such reporting. ${ }^{1}$ The policy otherwise known as the "Whistleblowing Policy" put in place by the Federal Ministry of Finance has been applauded by many, because of some remarkable successes it has recorded in its short time of existence, but needs to be invigorated if it should stand the test of time. The policy remains so, no matter how comprehensively couched, because it is bereft of a statutory framework to drive the entire programme and therefore is legally unenforceable. The paper therefore examines the concept of whistle-blowing, its implications and the imperative of having in place a normative, institutional and judicial framework that guarantees the protection of whistleblowers. The work acknowledges the risk of harm invited to individuals, who make disclosures without assurance of genuine protection and the chilling effect on those, who might otherwise speak up and thus fuelling cynicism, about the value of public engagement and discouraging these public spirited citizens, whose actions can contribute in no small measure to nip in the bud if not incinerate the cancer of corruption in Nigeria. The paper also examines the legal and socio-ethical barriers, to having effective whistle-blower protection legislation and makes far reaching recommendations, which takes account of these impediments and the possibility of extending the concept beyond corruption and to include reporting on activities of terrorist, kidnappers, militants and criminal herdsmen who have held Nigeria by the jugular. The research is non-empirical. It involved content analysis of legislations, case law, official government documents, journals and newspaper articles, sourced 
from the ABUAD Law Library and the internet. Empirical results of published works are also used to corroborate some of the conclusions reached in the paper.

\section{Concept of Whistleblowing}

The origin of the term whistleblower is traced to the practice of officers in London's first police force, who were equipped with whistles to be blown when they saw a crime being committed, in order to alert and seek the assistance of other law-enforcement officers and the general public. ${ }^{2}$ Although there is no settled legal definition of what constitutes whistleblowing, it has been termed as "alerting an organization, a competent authority or the public to concerns of malpractices, dishonest or illegal activity or to other risks to the public interest practices by employers". ${ }^{3}$ The 2009 OECD recommendation of the Council for Further Combating Bribery of Foreign Public Officials in International Business transactions (Anti-bribery Recommendation), in the context of international anti-corruption standard, refers to protection from "discriminatory or disciplinary action public and private sector employees who report in good faith and on reasonable grounds to the competent authorities. ${ }^{4}$

The Council of Europe Civil Law Convention on Corruption refers to "employees who have reasonable grounds to suspect corruption and who report in good faith their suspicion to responsible persons or authorities." ${ }^{5}$ The United Kingdom's PIDA makes reference to "any disclosure of information which in the reasonable belief of the worker making the disclosure, tends to show one or more of the following..." (The provision continues by listing a series of acts, including in relation to the commission of criminal offences). ${ }^{6}$ The common derivatives of these definitions of whistleblowing, tend to emphasis the workplace or wrongdoings connected to the workplace and reports or information disclosed by employees or workers. This restrictive interpretation is understandable in the context of the fact that, people working for companies or organisations are often the first to recognize malpractice, dishonest or illegal activity or other risks to the public interest in a wide range of areas. These areas include but not limited to consumer safety, environmental damage, professional misconduct, child abuse, financial embarrassment and corruption. ${ }^{7}$

Within the framework of its aim for the recovery of stolen public funds, the Nigeria Federal Ministry of Finance under its Whistleblowing Programme (WBP) defines a whistleblower, as "a person who voluntarily discloses to the Federal government of Nigeria, through the Federal Ministry of Finance, a possible misconduct or violation that has occurred, is ongoing or is about to occur with specific concerns which are in the public interests". ${ }^{8}$ Information that can be disclosed to the Ministry, include information on stolen and or concealed public funds, financial malpractice or fraud, corruption, collecting/soliciting bribes, violations of government's financial regulations amongst others. ${ }^{9}$ Although the definition proferred by the Federal Ministry of Finance is restrictive, it can still be accommodated within the avowed objective of the policy of the Ministry. Alerting an organisation, a competent authority or the public to concerns of malpractice, dishonest or illegal activity, or to other risks to the public interests to all intends fits into the definition of whistleblowing. The public interests dimension as

\footnotetext{
2 Council of Europe (2016) Protection of Whistleblowers: A Brief guide for Implementing a National Framework, Strasbourg, documents and Publications Department (SPDP) p.16

3 Ibid p.5

${ }^{4}$ OECD Convention on combating Bribery of foreign Public officials in Intentional Business transactions, Recommendation for further combating Bribery of foreign public officials in International Business transactions, Recommendation IX (iii)

${ }^{5}$ Council of Europe Civil Law Convention on Corruption (1999), Article9

6 United kingdom PIDA (1998), Part IV. A, section 43B.

7 Council of Europe op. cit p.5

8 (FMF- whistleblowing: frequently Asked questions, op cit

${ }^{9}$ Ibid.
} 
appearing in these definitions, effectively debunks the negative tags of 'informant', 'traitor', 'spy' or even a 'snitch', which is associated with being a whistleblower. What is reported are criminal offences, unethical practices and other wrong doings rather than a personal grievance.

\section{Theories of Justification of Whistleblowing}

What makes whistleblowing deserving of justification and therefore morally problematic is that, it usually involves an intention to prevent some bad thing that would otherwise occur or to reveal information that would not ordinarily be revealed. In the organisational setting, a mere individual cannot blow the whistle in any interesting sense, only a member of an organisation, whether current or a former member can do so. A police officer who makes public information about a robbery gang, though a member of the police force does not blow the whistle on the robbery gang in any interesting sense, he simply alerts the public. But where he goes out of his way to inform the public about, for example, his superiors hiring out guns to armed robbers or ordering abandonment of duty posts to facilitate robbery at banks, then whistleblowing becomes morally problematic. Questions could be asked about his loyalty to the police organisation and also betrayal of his colleagues and bosses. These moral issues arise because the police officer has given out information about his organisation which information, the organsiation will not ordinarily want revealed. Thus, in a real case of whistleblowing, the whistleblower reveals information he is entrusted with or gives out information on an organisation that prima facie deserves the whistleblower's loyalty. Two theories have evolved on the moral justification for disloyalty to an organisation by blowing the whistle. These theories are the standard theories and the complicity theory. According to Michael Davis, ${ }^{10}$ by the standard theory, whistleblowing is required because people have a moral obligation to prevent serious harm to others, if they can do so with little cost to themselves. The action is morally justified when it meets five criteria. In his complicity theory, Davis states that because the whistleblower is complicite in wrongdoing rather than from the ability to prevent harm, there is a moral obligation to right the situation. ${ }^{11}$

The complicity theory of justified whistleblowing has two advantages over the standard theory. The first is that, moral complicity itself presupposes moral wrongdoing, not harm. So complicity justification automatically avoids the paradox of missing harm which fits the facts of whistleblowing better than, a theory which emphasizes prevention of harm as represented by the standard theory. The second advantage is that complicity invokes a more demanding obligation than the ability to prevent harm does. We are morally obliged to avoid doing moral wrongs, but where despite our best efforts, we nonetheless find ourselves engaged in some wrong, we have an obligation to do what we reasonably can to set things right. ${ }^{12}$ If in expectation of some money to be paid into my bank account, I issued a cheque to another person, and unfortunately my expectation was dashed, I have a moral obligation to do all I can to alert the person to whom the cheque was issued and if possible quickly exchange the cheque with cash equivalent or withdraw the cheque completely.

\section{Benefits of Whistleblowing}

Encouraging the whistleblowing on acts of suspected corruption is essential in safeguarding public interests and promoting a culture of public accountability and integrity. It is an essential anti-corruption mechanism. Nigeria Minister of Information and Culture disclosed in February 2017 that the whistleblowing policy had yielded USD 151Million and N8 billion in looted

10 “Some Paradoxes of Whistleblowing” Business and Professional Ethics Journal 15(1)(1996)

11 Ibid.

12 Ibid. 
funds. ${ }^{13}$ The activities of whistleblowers led the Economic and Financial Crimes Commission (EFCC) to discover $€ 547,730$ Five Hundred and Forty Seven Thousand, Seven Hundred and Thirty Euros), $£ 21,090$ (Twenty One Thousand and Ninety Pounds) and \$ 5,648, 500 (Five million, Six Hundred and Forty Eight thousand, five Hundred Naira) in Balogun Market, Lagos. ${ }^{14}$ It was also reported that USD38,000,000 (Thirty Eight Million Dollars), £27, 000 (Twenty Seven Thousand Pounds) and $\$ 23,000,000.00$ (Twenty Three Million Naira) was found in a private residence in Ikoyi, Lagos based on information by a whistleblower ${ }^{15}$ Whistleblowing efforts culminated in the retrieval by the EFCC from Former the Group Managing Director of Nigerian National Petroleum Corporation (NNPC), the sum of USD9.8Million (Nine Million, Eight hundred thousand Dollars). ${ }^{16}$

Apart from recovering of looted funds, the activities of whistleblowers have been encouraging in stemming insurgency in the North Eastern part of Nigeria. Whistleblowers may also be needed to provide information on tracking down kidnappers, cattle rustlers, militant herdsmen and other peddlers of antisocial vices which are inimical to the peace and progress of the nation. Indeed buoyed by the gains from the recent whistleblowing policy in the recovery of looted funds, the Government of Nigeria has extended it to the mopping up of illegal arms and ammunition to stem the proliferation of illegal weapons which has aggravated insecurity in the country to a level unprecedented ${ }^{17}$. Thus, from bribery to corruption, fraud to human rights violations, whistleblowers can help in the fight against impunity by disclosing wrong doings in both the public and private sectors.

\section{Protection of Whistleblowers}

Encouragement of whistleblowing must be associated with corresponding protection for the whistleblower. Public spirited persons with courage to report infractions need to be protected from being subjected to intimidation and detriments. Afe Babalola lists such detriments in the nature of harassment to include legal action, criminal charges, social stigma and termination from any position, office, or job ${ }^{18}$ It is also reported that, individuals who have blown the whistle while with one employer and have subsequently left, have had difficulty securing further employment with a new employer as a result of being a known whistleblower. This has been refered to as a form of "blacklisting" of whistleblowers. ${ }^{19}$ In many countries, whistleblowing is even associated with treachery or spying. ${ }^{20}$ While discussing the risky nature of the business of whistleblowing, Afe Babalola poignantly recounted:

Indeed in some countries, whistleblowers have paid the ultimate sacrifice for daring to report wrongdoing. In India, an engineer Satyendra Dubey was murdered in November 2003. Dubey had blown the whistle in a corruption case in the National Highways Authority of India's Golden Quadrilateral project. Two years later, an Indian Oil Corporation Officer, Shanmughan Majunath, was murdered for sealing a petrol

\footnotetext{
13 Nigeria Government recovers \$151 Million, $\mathrm{N}$ 8million tooted funds through whistleblowers. Minister https://www.premiunmmesng.com: Accessed on April 20, 2017.

${ }^{14}$ EFCC uncovers another $€ 547,730, £ 21,090$ and N5.6 Million cash in Lagos. https://www.dailypostngr.com: Accessed on April 10, 2017.

15 EFCC finds $\$ 38$ Million, $€ 27,000$ and $\$ 23$ Million in General Road, Ikoyi Lagos. https://www.vanguardngr.com: Accessed on April 13, 2017.

16 How EFCC recovered \$9.8 Million from Yakubu, ex NNPC GMD. https://www.vanguardngr.com: Accessed on June 19, 2017.

17 The Punch, Editiorial, Illegal arms: Whistle-blowing to the rescue p. 20

18 Afe Babalola, Afe on Thursday: “Government 5\% Reward Policy on Whistleblowers: Need for Statutory Framework for Protection". Nigerian Tribune, January 12, 2017.

19 Department for Business innovation and Skills. "The Whistleblowing Framework a call for Evidence, July 2013".

20 David Banisar "Whistleblowing: International Standards and Developments" in Sandival, I (editor), Corruption and transparency: Debating the Frontiers between State, market and Society. World Bank-Institute for Social Research, UNAM, Washington, D.C. 2011 P.7 available at htpp: papers.ssrn.com/s013/papers.cfm?abstractid+1753180.
} 
pump that was selling adulterated fuel. A Karnataka official, SP Mahantesh, said to be a whistleblower in controversial land allotments by societies, was murdered in May 2012. He was working as Deputy Director of the audit wing in the state's co-operative department and had reported irregularities in different societies involving some officials and political figures. A senior police officer who alleged that a certain government official was corrupt and had embezzled large amounts of money was sent to a psychiatric hospital shortly after he made the revelations...

It was reported recently in Nigeria that one Ntia Thompson, a Director with the Directorate for Technical Co-operation in Africa, who blew the lid in a fraud that embarrassed the key masterminds of the directorate was compulsorily retired from the services of the directorate with effect from $7^{\text {th }}$ February, $201 .^{21}$

From the examples of India as epitomized by Afe Babalola and the recent example of Ntia Thompson in Nigeria and examples from other jurisdictions, the jury is in favour of protecting whistleblowers. Protecting whistleblowers facilitates the reporting of bribery, as well as the misuse of funds, waste, fraud and other forms of corruption. Citizens reporting in good faith suspected acts of corruption and other wrongdoings must be protected from retaliation for reporting, because whistleblowing is integral to efforts to combat corruption, promotion of public sector integrity and accountability.

\section{Framework for Protection of Whistleblowers}

The future of regulation of whistleblowing was shaped by the 1990s number of fatal disasters, such as the Pipe Alpha explosion and financial scandals such as Barings Bank and the Robert Maxwell fraud, after investigations in these debacles, revealed that staff had been aware of the physical or financial risks, but had been afraid to raise concerns which were ignored or were raised in the wrong way. ${ }^{22}$

There is no uniform means for establishing and implementing effective whistleblower protections. In some countries protection of whistleblowers can be found in dedicated legislation on whistleblowers protection, such as Japan's Whistleblower Protection Act (WPA) Act, No. 122 of 2004, South Africa's Protected Disclosures Act (PDA), Act No. 26 of 2000, or the United Kingdom's Public Interest Disclosure Act (UK PIDA), 1998. Protection may also be provided for in a country's criminal code, for example section 425.1 of the Canadian Criminal Code which prohibits retaliation against an employee who provides information about a crime. The United States Federal Criminal Code was amended by the Sarbanes-Oxley Act (SOX Act) to impose a fine and/or imprisonment for retaliation against a whistleblower that provides truthful information about the commission or possible commission of any federal offence to law enforcement authorities. ${ }^{23}$

Sectoral laws, such as anti-corruption laws, competition law, accountings and environmental protections laws, employment laws, company and securities'laws, may also make provision for whistleblower protections. Under such laws, protection may only be afforded to specific persons or for the reporting of specific offences. ${ }^{24}$ For example, Korea's Act on Anti-Corruption and the Establishment and Operation of the Anti-Corruption and Civil Rights Commission (ACRC Act) provides whistleblower protection to anyone who reports an act of corruption to the Commission. France's Code du Travail, also provides some protection measures for

\footnotetext{
21 Ministry Fires Whistle-blower who exposed \$229, 000 fraud vanguradngr.com 4 th march, 2017.

22 Department for Business innovation and Skills, op. cit.

23 OECD, Study on whistleblower Protection Frameworks, Competition of Best Practices and Guiding Principles for Legislation.

24 OECD ibid.
} 
employees who report health or safety issues, or instances of sexual harassment. ${ }^{25}$ In the United States, the Dodd-Frank Wall Street Reform and Consumer Protection Act (Dodd-Frank Act), protects whistleblowers who provide information to the Securities and Exchange Commission (SEC), relating to a possible violation of securities law that has occurred, is ongoing or is about to occur. ${ }^{26}$

Whistleblower protection may also be found in laws regulating public servants. Canada's Public Servants Disclosure Protection Act (PSDPA, 2005) for example, provides protection from reprisals for public servants who disclose wrong doings in or relating to the public sector. The public service codes of ethics and conduct of some countries may provide for whistleblower protection within the public sector. The Australian Public Service Code of Conduct makes express references to whistleblower protections for public service employees who report breaches or alleged breaches of the code to an authorized person. ${ }^{27}$

International instruments aimed at combating corruption have also recognised the importance of having whistleblower protection laws in place, as part of an effective anti-corruption framework. Such protection requirements have been introduced in the United Nations Convention Against Corruption. ${ }^{28}$ The 2009 OECD Recommendation of the Council for Further Combating Bribery of Foreign Public Officials in International Business Transactions (AntiBribery Recommendation); ${ }^{29}$ the 1998 OECD Recommendation on Improving Ethical Conduct in Public Service; ${ }^{30}$ the Council of Europe Civil and Criminal Law Conventions on Corruption; ${ }^{31}$ the Inter-American Convention against Corruption, Article 111(8); and the African Union Convention on Preventing and Combating Corruption, Article 5(6).

\section{Nigeria's Whistleblowing Programme}

The response of Nigeria to these developments, was the introduction by the Federal Ministry of Finance in 2016 of an initiative called: "Whistle Blowing programme" which aims at setting the framework for the recovery of stolen public funds to finance Nigeria's infrastructure deficit and as a means to fight financial crimes and corruption. ${ }^{32}$ The programme encourages persons to report information on mismanagement of public funds and assets, violation of financial regulations, financial malpractices, fraud, theft, amongst others. ${ }^{33}$ Whistleblowers may submit such information through a FMF-Whistleblowing online portal or writing to FMF, Presidential Initiative on Continuous Audit Unit or by telephone. A whistleblower that provides information that directly leads to the voluntary return of stolen/concealed public funds/assets may be entitled to between $2.5 \%-5 \%$ of the amount recovered. ${ }^{34}$ For the protection of the whistleblower, the programme provides that the identity of a whistleblower will be maintained fully within the limitation of the law. If whistleblowers do not want to disclose their identity, (i.e. confidential whistleblowing), there will be no record of such. If they however choose to do so, it will only be disclosed in circumstances required by law. There is

\footnotetext{
25 France Code du travail, Article L 1152).

26 OECD op.cit.

27 Australian Public Service Code of Conduct, Chapter 17 (Whistleblowing).

28 UNAC Articles 8, 13 and 33.

29 (OECD Anti-Bribery Convention, 2008 recommendation for further combating of Bribery of Foreign Public Officials in International Business transactions, section ix.iii and section X.c.v, and Aneex ii to the Recommendation, Good Practice Guidance on International Controls, Ethics and Compliance, section A.ii.ii).

30 (OECD Recommendation on Improving Ethical Conduct in Public Service, Principle 4)

31 Council of Europe Civil Law Conventions on Corruption, Article 9; Council of Europe criminal Law Convention on Corruption, Article 22.

32 Federal Ministry of Finance, op. cit.

33 Thompson Okpoko \& Partners “The Federal Ministry of Finance's Whistleblowing Programme: the Need for a Law to Protect Whistleblowers".

${ }^{34}$ Federal Ministry of finance, op.cit.
} 
also a complaint procedure in place, if any whistleblower feels he or she has suffered adverse treatment for whistleblowing.

\section{Imperative of Statutory Protection}

As commendable as the Federal Ministry of Finance Whistleblowers programme is, it is still work in progress. As eloquently posited by Afe Babalola, the programme elicits some concerns, the most prominent of which is the absence of a legal framework to guide the entire process. ${ }^{35}$ In similar vein, Onakoya and Moses observed that in Nigeria the lack of statutes on whistleblowing plus the weak institutions (legal and political) constitute a huge hindrance for potential whistleblowers. Also commenting on the Federal Ministry of Finance whistleblowing programme, Thompson Okpoko \& $\mathrm{Co}^{36}$ remarked that, although the whistleblowing policy appears to be arguably effective in view of the remarkable successes, it had achieved in its short life, any policy not backed by law is useless. Similar sentiments have seen expressed by commentators like Niyi Akinnaso, ${ }^{37}$

\section{Reasons for Whistleblower Protection Legislation}

According to Ibrahim Sule ${ }^{38}$, the main purpose of whistleblower protection legislation is to give adequate and appropriate legal protection, to workers and employees both in public and private sectors and to other persons and citizens who decide, to disclose information which will otherwise lead to some accidents, loss of lives and properties and other misappropriation of public funds. Ibrahim Sule noted further that, a legislation will also de-stigmatise whistleblowing, encourage others to speak out in public interest, thereby provide a real alternative to silence. ${ }^{39}$ As noted by Afe Babalola, secrecy is often a factor which permits many acts of corruption to go undetected or unreported, and therefore any, law which will encourage persons in the know of such acts to come forward and reveal them is welcome. ${ }^{40}$

An OECD supported report, disclosed that translating whistleblower protection into legislation legitimises and structures the mechanisms under which whistleblowers can disclose wrongdoings in the public and private sectors and protects them against reprisals. ${ }^{41}$ According to David Banisar, if adequately implemented, legislation protecting whistleblowers can become one of the most effective tools to support anti-corruption initiatives and detect and combat corrupt acts, fraud and mismanagement. The absence of appropriate legislation impedes the fight against corruption and exposes whistleblowers to risks of retaliation. ${ }^{42}$ Commenting on the Nigeria Ministry of Finance Whistleblowing programme, Thompson Okpoko \& Co observed that, the programme remains a policy and unenforceable because it is not backed by any law. They submitted further that, a policy merely sets out the intention of the government and outlines the principles and methods by which a government is guided ${ }^{43}$. In support of this contention, they called in aid this succinct interpretation of the term policy by the Court of Appeal thus:

\footnotetext{
35 Afe Babalola, op. cit.

36 op.cit

37 Nigeria's whistleblower policy Punch Newspaper(December 27, 2016)] http://punchng.com/nigerias-whistleblowerpolicy.accessed on 30th June, 2017.

38 Sule, I whistleblowers' protection legislation. In search for model for Nigeria ippa.org>images>ippc4>pp18-8.

39 Ibid.

40 Op. cit

41 OECD study on G20 Whist blower Protection Framework, Compendium of Best Practices and guiding Principles for Legislation. Study agreed on at the Bali meeting of Anti-Corruption working Group (AWG) on 12-13 May, 2010. P.15. www.cleangovbiz.org. Accessed on June 20, 2017.

42 Ibid.

43 Ibid
} 
...set of ideas or a plan of what to do in particular situations that has been agreed officially by a group of people, a business organisation, a government or a political party. ... It is the general principles by which a government is guided in its management of public affairs...

Furthermore, it was held in Wilkie $v$ FGN \& $\mathrm{Ors}^{45}$ that, a policy statement or guidance by the Federal Government does not give rise to contractual relationship between the government and a third party and its non implementation does not entitle the third party to a legal redress against the government.

The effect of the foregoing is that, in spite of the lofty protections afforded under the whistleblowing programme, the citizen who blows the whistle and suffers any detriment cannot legally hold the government or its functionaries to promises made under the programme. Enshrining whistleblower protection in legislation, is important, as its clarifies what is expected of employers and competent authorities, informs individuals of their right to disclose information, particularly outside the workplace, and how to seek a remedy if they suffer unfairly for doing so ${ }^{46}$.

\section{Features of Whistleblowers Protections Legislation}

A wide range of sources may serve as the bases for providing whistleblower protections. Such laws may be in form of a dedicated legislation on whistleblower protection or may be found in a country's criminal law code. Sometimes it may be found in sectoral laws; such as anticorruption law; accounting laws, procurement laws or even laws regulating public servants. According to the international best practice in drafting whistleblower protection legislation, some salient hallmarks cannot be negotiated. These hallmarks must be contained in a virile legislation on whistleblowing and are discussed hereunder:

\section{Comprehensive and Stand-alone Legislation}

The enactment of a comprehensive, dedicated law as the bases for providing whistleblower protection is generally considered the most effective legislative means of providing such protection. It has been posited by Banisar that such legislation may give the law heightened visibility and thereby making its promotion easier for governments and employers. ${ }^{47}$ Also it has been submitted that, enactment of stand-alone legislation as opposed to piece meal or sectoral approach could also contribute to ensuring legal certainty and clarity ${ }^{48}$. Fragmented approach may result in protection only of specific persons or for the reporting of specific offences and thus resulting in legal uncertainty and ambiguity. A comprehensive and standalone legislation should be compressive enough in the coverage of workers both in the public and private sectors, including those in the informal economy and those under informal arrangements, such as consultants. Adequate provision must also be made to cater for persons who are not employees, but are affected one way or the other by an organisation's activities. The law should also ensure that protection is not limited to reporting of corruption, or accounting defalcation, but to include vices like terrorism, kidnapping, child abuse, slavery, robbery and related issues which endanger civilized cohabitations or violates the public interest.

48 Transparency international, recommended principles for whistleblowing legislation, Recommendation 23. 
The level of protection to be afforded certain public sector employees, especially those engaged in sensitive areas of work is a vexed issue. How is protection to be afforded a public servant who discloses national security related information? Different and sometimes contradictory interest comes to the fore when disclosures involve national intelligence information. The whistleblower's freedom of expression and the people's freedom of information collide with the intelligence agent's duty to protect secret information. Transparency and democratic accountability clashes with the need for secrecy for intelligence operations to be effective. Yet, the legitimate need for secrecy and confidentiality should not be used as a cloak to conceal human rights violations committed by government agents. ${ }^{49}$ The disclosures by Edward Snowden awaken the world to the different programmes that intelligence agencies use on a daily basis which interfere with the privacy of citizens. His disclosures, a public service enabled the world community to discover that, (NASA) could record every single phone in an entire country, ${ }^{50}$ access personal data held by leading internet companies with or without their consent, ${ }^{51}$ tap the phones of German Chancellor Merkel along with those of 121 other heads of states and government, and even spy on, the United Nations, the European Union and other International Organisations. ${ }^{52}$

By his gesture, although derided by some as a traitor, others regard him as a hero to the extent that, more than 100,000 supporters of his cause signed an online petition asking President Obama to pardon him by June, 2013. He however, faces serious espionage charges under United States legislation without being able to raise a public interest defence. It is submitted that where public interests in the disclosure of information outweighs any harm resulting from disclosure, the whistleblower must be afforded protection. Legislation must therefore be geared towards a framework which can reconcile legitimate national security concerns with the fundamental human right to privacy. ${ }^{53}$

\section{Effective Institutional frameworks and clear procedures for reporting.}

A whistleblower's legislation should make provision for one or more channels by which disclosures can be made. This may be for internally or externally designated bodies. It has been opined that internal reporting is usually encouraged and external reporting channels used only as last resort, for example through requiring a higher threshold of conditions for external reporting. ${ }^{54}$ Disclosures may also be made to the public where there is not sufficient time or opportunity to utilise either of the internal or external channels. In addition, procedures for taking up the report and investigating must also be clearly specified.

\section{Clear definition of protected disclosures and persons afforded protection.}

One of the main objectives of whistleblower protection laws is to promote and facilitate the reporting of illegal, unethical and dangerous activities and it behoove on such legislation to provide a clear definition of the scope of disclosures that are afforded protection. ${ }^{55}$ In the context of using whistleblower protection mechanisms as a means of combating corruption, for purposes of clarity and legal certainty, the disclosure of corruption offences may explicitly be

\footnotetext{
49 Explanatory Report of Peter Omtzist: Rapporteur, Netherlands Group of the European People's Party. Draft Resolution adopted on $18^{\text {th }}$ March, 2015.

50 see The Guardian by $6^{\text {th }}$ September, 2013 "Revealed how US and UK spy agencies defeat Internet Privacy and Security".

51 See The Intercept of 19 may, 2014, "Data Pirates of the Caribbean: the NSA is Recording Every Phone |Call in the Bahamas".

52 The Guardian of 30 June, 2014, 'New NSA deals show how US is bugging its European allies".

53 Edward Snowden, is an American, a former Central Intelligence Agency (CIA) employee, and former contractor for the United States who copied and leaked classified information from the National Security Agency (NSA) in 2013 without authorization. He has been granted asylum in Rusia till the year 2020. https://www.biography.com/people/edward-snowden21262897. Accessed August, 4, 2017.

54 OECD Whistleblower Protection: encouraging reporting, July, 2012.

55 D. Banisar, op. cit.p. 22
} 
referred to in the legislation, or the reporting of crime more generally. Protected disclosures may require set minimum thresholds on the extent of the wrongdoing before whistleblower protection may be triggered. Thus, distinguishing between trivial, frivolous or vexations violations which there is no obligation to investigate and gross or serious violations which will readily attract the attention of investigators.

With respect to the scope of courage of protected persons, the net should be wide enough to cover all persons who may potentially come to know of acts that may be disclosed. For example, coverage should include public servants, permanent employees, former employees, volunteers, job applicants, the unemployed and even persons who have been blacklisted and family members. ${ }^{56}$

\section{Protection against Retaliation}

It is not uncommon to find a whistleblower being discriminated against or being, visited with retaliatory consequences. A whistleblower protection law should provide comprehensive protection against discriminatory, retaliatory actions or harassment. The law should set out broad employment protections including direct or indirect disciplinary action, dismissal or discrimination, particularly with regard to remuneration, training, postings, promotion, contract renewal and any other employment related reprisals.

These protections must be fortified with the provision in the law of a clear and effective channel for reporting retaliation. It is also important to highlight in the law, remedies available for whistleblowers who have suffered some form of reprisals as a result of their actions. The remedies should cover all direct, indirect and future consequences of the reprisals and can include return to employment after unfair termination, transfers to comparable job position, compensation for harm suffered that cannot be remedied by injunctions and criminal sanctions for employer's retaliatory actions. All these will be without prejudice, to the right by the whistleblower to approach the court, if the remedial action was in sufficient or unsatisfactory. In effect, the whistleblower is entitled to a fair hearing before an impartial forum with a full right of appeal. He or she must not be denied of a 'genuine day in court'.

\section{Incentives to Encourage Reporting}

To encourage whistleblowing, a reward system, including monetary rewards could be included in the law as part of the whistleblowing protection mechanism. In the United States the government through the U.S. False claims Act, allows a whistleblower to receive up to $30 \%$ of the amount retrieved by the government. ${ }^{58}$ The South Korean Anti-Corruption Act, allows whistleblowers to recover up to $20 \%$ of the recovered amount. ${ }^{59}$ Indonesian law also provides for the granting of "tokens" of appreciation to whistleblowers that have assisted efforts to prevent and combat corruption." ${ }^{\prime 60}$

\section{Mechanisms for raising regular awareness to encourage reporting of corruption and wrongdoing}

For the successful implementation of whistleblower protection legislation, it is incumbent to have in place an effective awareness-raising, communication and training mechanisms. Special programs for awareness raising and training in both the public and private sectors, under the

\footnotetext{
56 U4 Anti-Corruption Resource Centre, Good Practice in Whistleblowing Protection Legislation (2009), p.4

57 Transparency International, Recommendation Principles for whistleblowing Legislation, Recommendation 20

58 Paul Latimer and A.J. Brown Whistleblower Laws: International Best Practice (November 01, 2008) Monash University

Department of Business Law \& Taxation Research Page No. 1326766 pp. 21, 22.

59 Korean Anti-Corruption Act, 11.7,36,37.

60 Law No.31 of 199 on the Eradication of the Criminal Act of Corruption, Article 42.
} 
supervision of whistleblower programme command or agencies, created to superintend this role to inform citizens of their rights through training and sensitisation. The law may also require that, employers post and keep posted, notices informing employees of their rights in connection with protected disclosures. ${ }^{61}$ Raising awareness about the importance of whistleblowing and afforded protections, may contribute to changing negative cultural perceptions and public attitudes towards whistleblowing and thus considering it an act of loyalty to organisation nay country. The training must also be extended to the public sector, to ensure that managers are adequately trained to receive reports and to recognise and prevent occurrences of discriminatory and disciplinary actions taken against whistleblowers.

\section{Protection of free speech and freedom of information}

Whistleblowing, except in a few specific cases, where there may be a professional duty to disclose, for example in the case of police officers, needs to be understood as an act of good citizenship, from individuals who speak up in the interest of others or of the services the organisation is meant to provide. Therefore protection should flow from the democratic principles of free speech and freedom of information. Legislation should therefore ensure that, where a disclosure is made in the public domain, any interference with the right to disclose that information is only that which is necessary in a democratic society. 'Gagging clauses' and secrecy laws should be eschewed.

\section{Periodic evaluation and review of the whistleblower protection framework.}

Statute must provides for an independent public body charged with the responsibility of ensuring systematic data collection regarding the number of cases, if follow-up took place and the results obtained, so as to facilitate in assessing the progress or lack of, in the whistleblower mechanisms.

\section{Barriers to Whistleblowing}

Apart from the fear of retaliation which may discourage whistleblowing, there are other barriers militating against whistleblowing. Many countries count on Official Secrets Acts or classified information which prohibits the release of information obtained under government employment under certain circumstances. Even the celebrated Freedom of Information Act, 2011 to some extent protects whistleblowers in the public sector by removing legal obstacles that affect disclosure of information. However, the protection in not enough, the Act still leaves the public officer vulnerable to dismissals, suspensions or demotions as a result of making a disclosure. The Act does not extend protection to private sector organisations. There are limitations as to what can be accessed in the operation of the Act. Only sections 1 and 3 grant access to information with as many as ten sections, namely sections $7,11,12,14,15,16,17,18,19$ and 26 denying public access to information. Barrier also exists in the form of libel and defamation laws, which may be used to deter whistleblowers from disclosing illegal activities. To maximise the flow of information necessary for accountability, reliable protected channels must be available for those who choose to make confidential disclosures. Many Nigerians are wary of reporting suspicious persons or activities to the security agencies because confidentiality is not always guaranteed. There are instances where people report goings on to the police and before the blink of the eye, the suspect tracks down the individual who reported the matter to the police. This means that an insider privy to the event leaked the information

\footnotetext{
61 For example in the United States, the Occupational Safety and Health Administration Act (OSHA) requires Federal Agencies to post certain information about whistleblower protection in order to keep employees informed of their rights in connection with protected disclosures.
} 
to the suspect usually for a fee. ${ }^{62}$ Some companies have strict rules for employees concerning the duty of loyalty and confidentiality (business and trade secrets). Companies may require employees to sign confidentiality clauses. Some of these "gag orders" found in organisation's rules and policies or non-disclosure agreements may sometimes override free expression rights and impose prior restriction on speech.

\section{Efforts at Having a Legal Framework for Whistleblower Protection in Nigeria}

The first attempt at having a comprehensive law for the protection of whistleblowers in Nigeria was contained in the "whistleblower Protection Bill, 2008", which comprised twentytwo sections. ${ }^{63}$ The bill sought in the main, to provide for the manner in which individuals may in the public interest, disclose information that relate to unlawful or other illegal conduct or corrupt practices of others; and to provide for protection against victimisation of disclosers. A second bill meant to complement the first, was captioned "Safeguarded Disclosure (Whistleblowers, Special Provisions, etc) Bill, 2009", which made provisions for the procedure in terms of which persons employed in the public and private sectors may disclose information regarding unlawful and other irregular practices and conduct in the workplace and to provide protection against any occupational detriment or reprisals of a person making such disclosures.

Apart from evidence of the existence of the sponsors of these bills, namely, Senators Ganiyu Solomon and J.H Agoda respectively, there was no record of progression of these bills. It is doubted if they ever progressed beyond the first reading stage or even got to that stage. It is however pertinent to comment on the noted shortcomings of both bills, which militates against international best practices in whistleblower protection legislation.

The term 'whistleblower' carries with it negative connotations, and therefore a more respectable and decent term should have been used to carry a stronger message that, protection is given by the provisions of the bill to those courageous and patriotic persons making disclosure of wrongdoings in the public interest. ${ }^{64}$ Although the bills defined protected disclosure, forms of wrongdoing and strengthens corporate responsibility by protecting private sectors whistleblowing, it makes no provision for the establishment of public interest disclosure agency or the establishment of a whistleblowers support agency. The bills do not also make provision for a reward mechanism for whistleblowers. The remedial avenues provided under the bills are also not as elaborate as to meet the standard of international best practices.

In 2017, the hope of a comprehensive legislation for the protection of the whistleblower was revived, with the passage by the Nigerian Senate of the Whistleblower Protection bill, sponsored by Senator Abiodun Olujimi in 2016. The law is known as "An Act to Protect Persons making Disclosures for the Public Interest and Others from Reprisals, to Provide for the matters disclosed to be Properly Investigated and Dealt with and for Other Purposes Related Therewith." The legislation seeks to ensure that, persons who make disclosures and persons who may suffer reprisals in relation to such disclosures are protected under the law. The bill also specifies those who are qualified to make disclosure of improper conducts; the procedure for making disclosures; and the protection due to whistleblowers.

\footnotetext{
62 Don Okere, Nigeria's Whistleblowing Policy: Urgent Case for Whistleblowers Protection Law. Thenigerialawyer.com accessed $8^{\text {th }}$ May, 2017.

63 Sule, op. cit.

64 Sule, op. cit p.18; See for example the United Kingdom legislation titled: Public Interest Disclosure Act, 1999 (PIDA);

Protected Discolosure Act, 2000 South Africa or the New Zealand Protected Disclosoures Act, 2001
} 
Persons who disclose are not to be subjected to victimisation by their employers or fellow employees. Additionally, the bill enable persons who make disclosures to take legal action if they are victimised, dismissed, suspended, declared redundant, transferred against their will, harassed or intimidated in any manner. ${ }^{65}$ The Senate has also passed the closely related "Witness Protection Programme Bill," which seeks to promote law enforcement by facilitating the protection of persons who provide information that assists law enforcement agencies. The bill apart from protecting investigators, prosecutors and members of the judiciary, increases the incentive for persons with useful information to testify when required to do so. The passage of these bills, represent progressive steps towards ensuring the institutionalisation of a whistleblower culture in Nigeria. It is hoped that the Nigeria's House of Representative will also expeditiously pass these bills and the Nigeria President will with equal zeal append his assent.

\section{CONCLUSION}

Whistleblower protection has been recognized by all major international instruments concerning corruption. Public and private sector employees have access to up-to-date information concerning their workplaces and are usually the first to recognise wrongdoings. However, those who report wrongdoings may be subject to retaliation, such as intimidation, harassment, dismissal or violence by their colleagues or superiors. Even in some countries, whistleblowing is associated with treachery or spying. In Nigeria the whistleblower policy introduced by the Federal Ministry of Finance has recorded appreciable gains, but lacks a legal framework to drive it to ensure whistleblower protection.

The Whistle Protection Bill and the Witness Protection Bill are at also various stages of legislative process before the President's final assent to give then force of law. It is hoped that if expeditiously passed, the risks associated with whistleblowing for those who in good faith and on reasonable grounds, speak out against suspected acts of wrongdoing, will be assured of protection against retaliation and backlash.

The comprehensive whistleblower protection framework suggested by this paper will ensure that whistleblowers are protected by law and public interest reports or disclosures are effectively acted upon. The legislation must be specific, clear, complete and simple in order to properly protect whistleblowers. It must also guarantee effective enforcement mechanisms for the right and remedies of the whistleblowers. A reward mechanism for courageous whistleblowers must also be legally backed. In this respect, rewards should not be limited to those whose efforts have led to the recovery of looted funds, but be extended to those who disclose useful information on militants, kidnappers, insurgents, terrorists and criminal headsmen who have held Nigeria by the jugular.

Finally, the implementation process must be backed by an unequivocal political will, ensuring independence in the investigation process and confidentiality of the identity of the whistleblower. Passing of the bills are also critical to foreign investors who are interested in the protection of the whistleblowers and their citizens, as the culture of disclosing wrongdoings in the public interest is accepted and acclaimed globally as effective tools of good governance and curbing of corruption. In this wise Nigeria cannot continue to tarry but take the driver's seat.

65 Olusola Babarinsa “Senate Passes Whistleblower Protection Bill into Law" Punch 19th July, 2017 


\section{ACKNOWLEDGEMENT}

The writers are eternally indebted to Aare Afe Babalola, OFR, CON, FNIALS, SAN, LL.D (LONDON), LL.D (UNILAG), FCARB, D.L.H. (NDA) Founder and President Afe Babalola University, Ado-Ekiti, Nigeria whose platform in authoritative Nigerian Dailies principally inspired this modest contribution. 